\title{
The Consolidation of a Practice: The Case of Packard Motor Car Factory in Detroit
}

\author{
By Pedro Belo Ravara*
}

This paper will discuss the impact of one of the first factory buildings as a functional and transitory paradigm in the modern era. The Proto-modern model I shall be referring to is the Packard Motor Car Company of Detroit, Michigan. It is still in remarkable running order and it is hoped that new use will be made of it.

\section{Introduction}

The History of Modern Architecture has focused on theoretical and historical matters by studying model or paradigmatic buildings which represent it in some way. Nevertheless, the theoretical and practical dimension has been side-stepped not deliberately, perhaps - but owing to the particular academic training of the specialists. As a matter of fact, the tradition of teaching Fine Arts was based on singling out models as a way of sustaining theory and criticism, thus down-playing the pragmatic role social and economic conditioning factors affecting the practical outcomes, the "modus facienti", of people in the profession, such as builders or entrepreneurs.

Be that as it may, the relationship between practice and theory or modernhistory theory is neither evident nor clear. The iconic models representing the history of architecture have always been very special cases that convey neither the "ordinariness" nor the anonymity of building practices, nor indeed, the outcomes which Hitchcock and Johnson, seconded by Alfred Barr, reckoned were the International Modern Style interpreting the revolutionary social spirit affecting the whole of Europe during the 1920s. ${ }^{1}$

The iconographic buildings of the Moderns living in the 1920s celebrated the individualistic traits of their architects. Owing to the fact that they were modern, and as such, were concerned with regulating architectural practices through their projects and buildings, they gained their autonomy as masters/authors by making a break with at least one of the three defining principles of the International Style. The principle of "regularity as against symmetry" was denied by the extraordinary qualitative irregularity of their work as well as the unlikelihood of obtaining any sort of constructive standardization. The classical understanding of a mirrored or reflected symmetry was now replaced by a modern concept of symmetry in which translation and repetition acquired its own degrees of symmetry. Regularity thus allowed the construction system to be increased by simple repetition in translating

\footnotetext{
*Assistant Professor, School of Architecture University of Lisbon, Portugal \& Guest Professor, Frankfurt University of Applied Sciences, Germany.

1. See H. R. Hitchcock and P. Johnson, The International Style (New York and London: W. W., 1995).

2. Idem, 37.
} 
a structural module. The building was now viewed as an architectural representation from beginning to end and from top to bottom, in this way refuting classical architectural representational values, which had already been held up for questioning throughout the $19^{\text {th }}$ century.

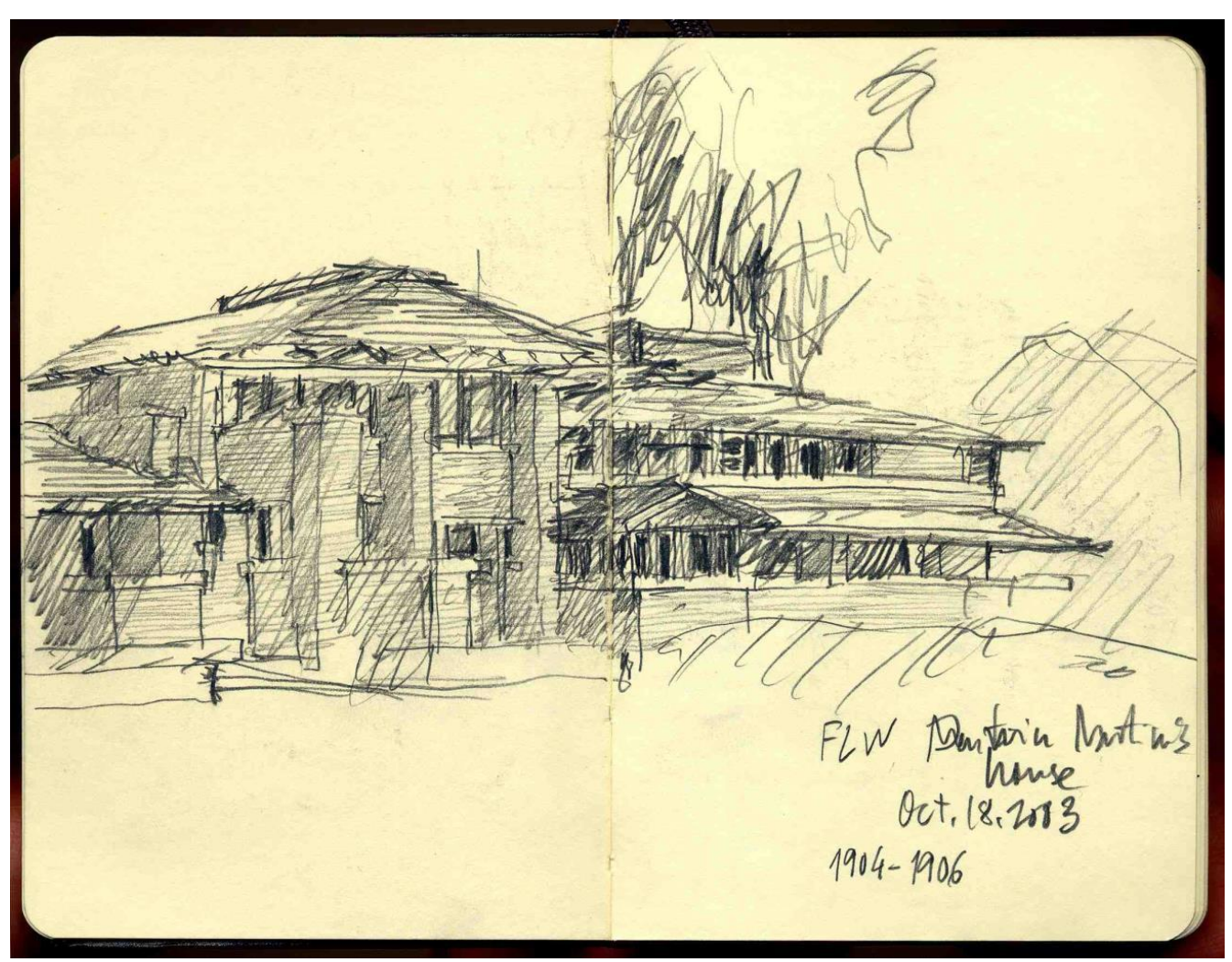

Figure 1. Martin Darwin House, Frank Lloyd Wright

Source: Drawing by the Author.

Buildings in the iconography of modern architecture thus tended to reject this compositional/constructive regularity. They were therefore buildings which stood out against what was the "regular" architectural currency of the day, at least the buildings which have been most commonly applauded. For example, it is arguable whether Frank Lloyd Wright's Martin Darwin House, 1904 (Figure 1), conforms to the other two principles put forward by Hitchcock and Johnson in 1932: "volume as against mass" and "absence or refusal of decoration."3

3. Idem, 37 . 


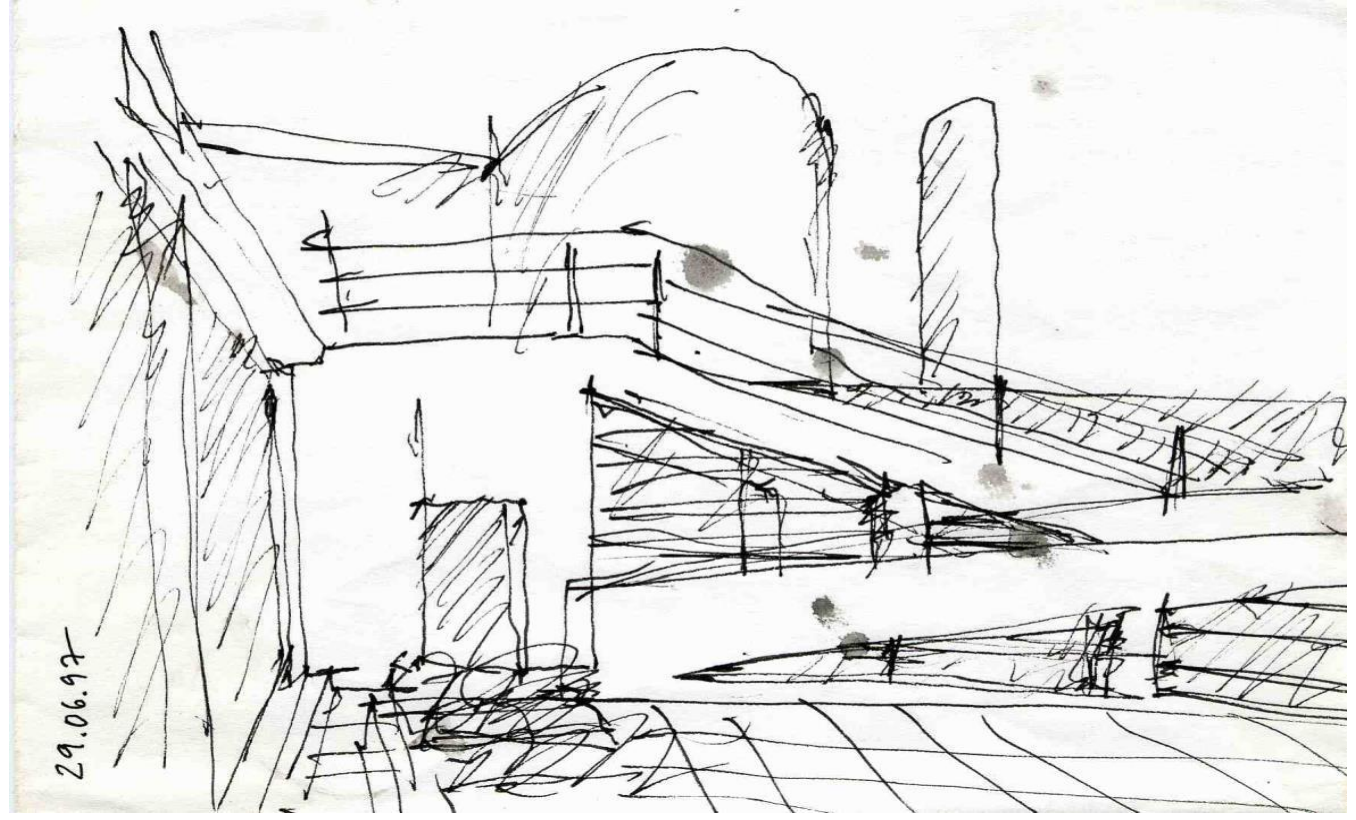

Figure 2. Ville Savoie, Le Corbusier

Source: Drawing by the Author.

Or could it be that Ville Savoie, built in 1929 (Figure 2), was the result of the designer's effort to really standardize building processes and practices, thus helping to readdress the social question about regular non-skilled manpower because democracy had opened the door to jobs-for-all?

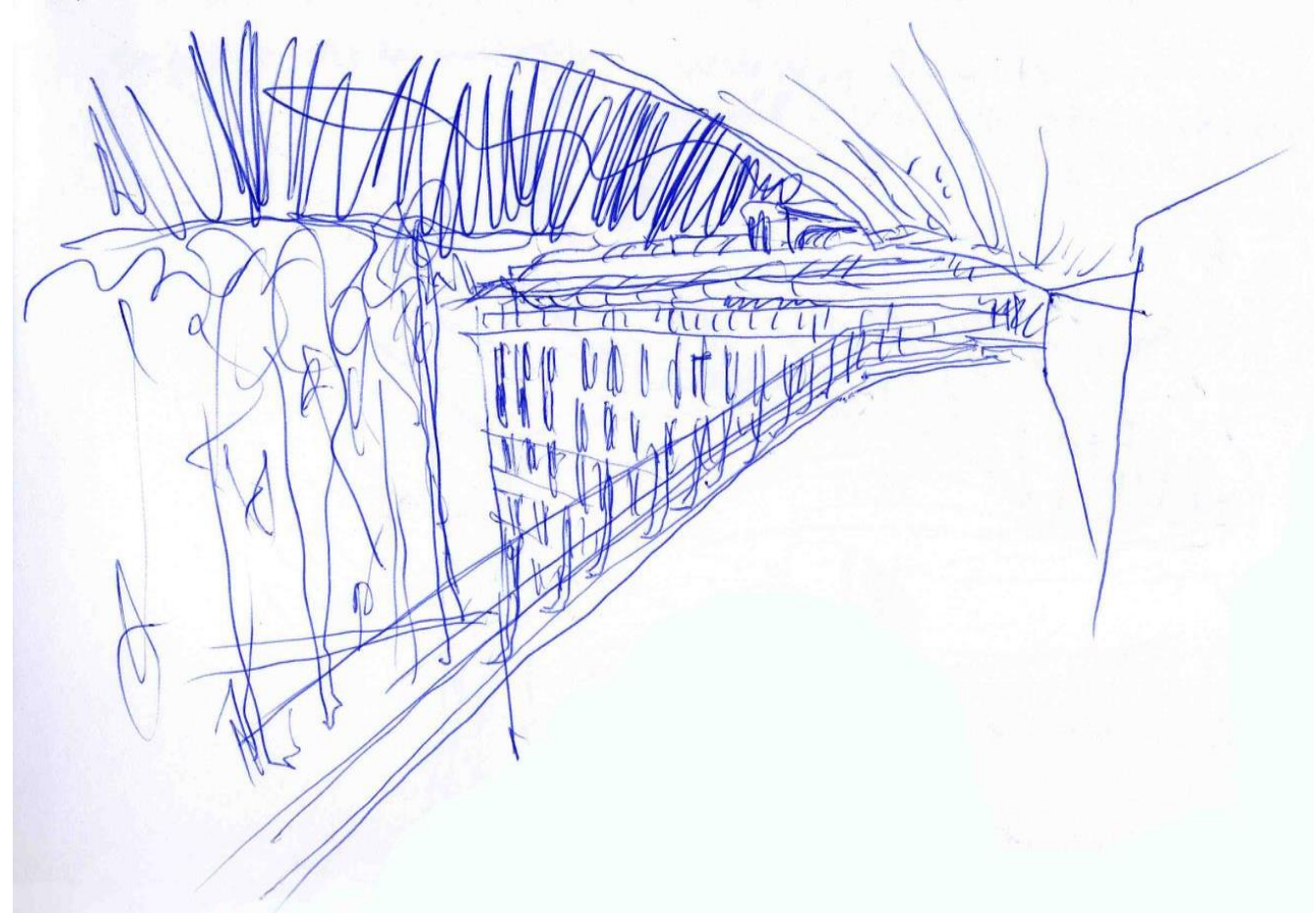

Figure 3. Paimio Sanatorium, Alvar Aalto Source: Drawing by the Author. 
Take the Paimio sanitarium, built in 1929-33 (Figure 3). The fact that it was built to integrate into and respect the surrounding landscape and environment takes on particular importance and is of unquestionable iconographical value on the drawing boards and blocks of students and architects in Northern Europe.

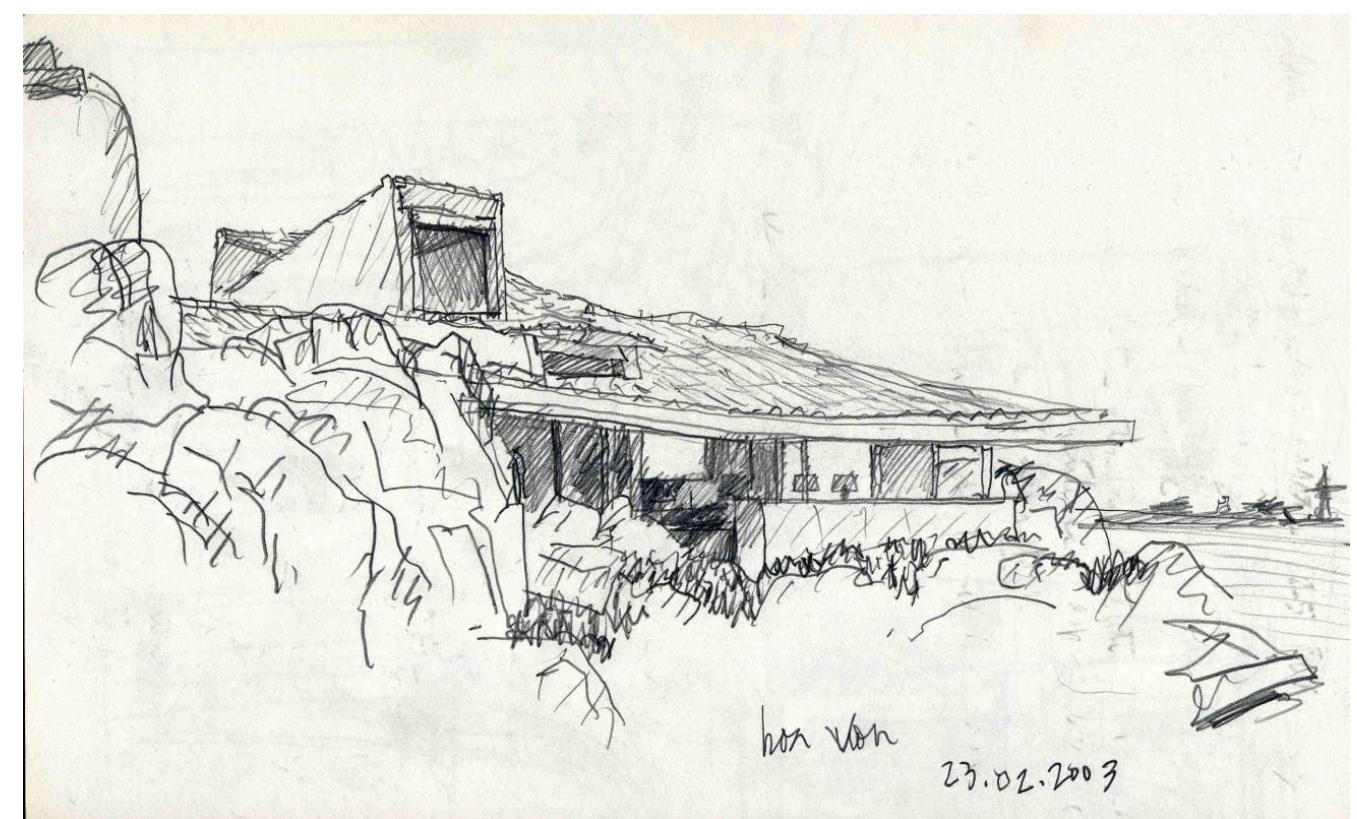

Figure 4. Boa Nova Tea House, Siza Vieira

Source: Drawing by the Author.

The teahouse in Matosinhos, designed and built between 1958 and 1963 (Figure 4), was designed by Álvaro Siza Vieira who went back to his Altean lessons as a way of closing the door in his work, on a modernism that was both critical and aware of the on-going conflict with his basic principles.

How may we clearly understand, therefore, the Modern Movement as an answer to the modern spirit that emanated from the social revolution in which jobs, the division and scientifically-qualified methods of management and production, the standardization and industrialization of products and landscapes under construction all made part of unstoppable processes that would decisively influence our cities and buildings? Probably we have to look back to the protomodern "functionalist" models.

\section{Car Factories as the "Functional" Proto-Modern Architectural Buldings}

The question of functionality in architecture became a central issue in the Modern Movement and in defining modern life throughout the $20^{\text {th }}$ century. Apart from spatial issues proper to the Modern Movement, such as a free plan and spatial fluidity functionality in architecture has also been understood through the simple essential expression of materials, building processes and the immediate need for space, light, insulation, etc. This architectural truth has to do with the idea of 
function while constructive functionalities may be represented and understood in a pedagogical way.

Connected with the factory's activity and performance is the building process itself, its material and expressive qualities being the representative languages of the powerful, growing industrialization which modernized the USA. Added to these factors is the anonymous nature of the shapes and processes promising to populate the horizon, or the infinite, where methodological standardization, repetition, homogenization and regularity become functional terms.

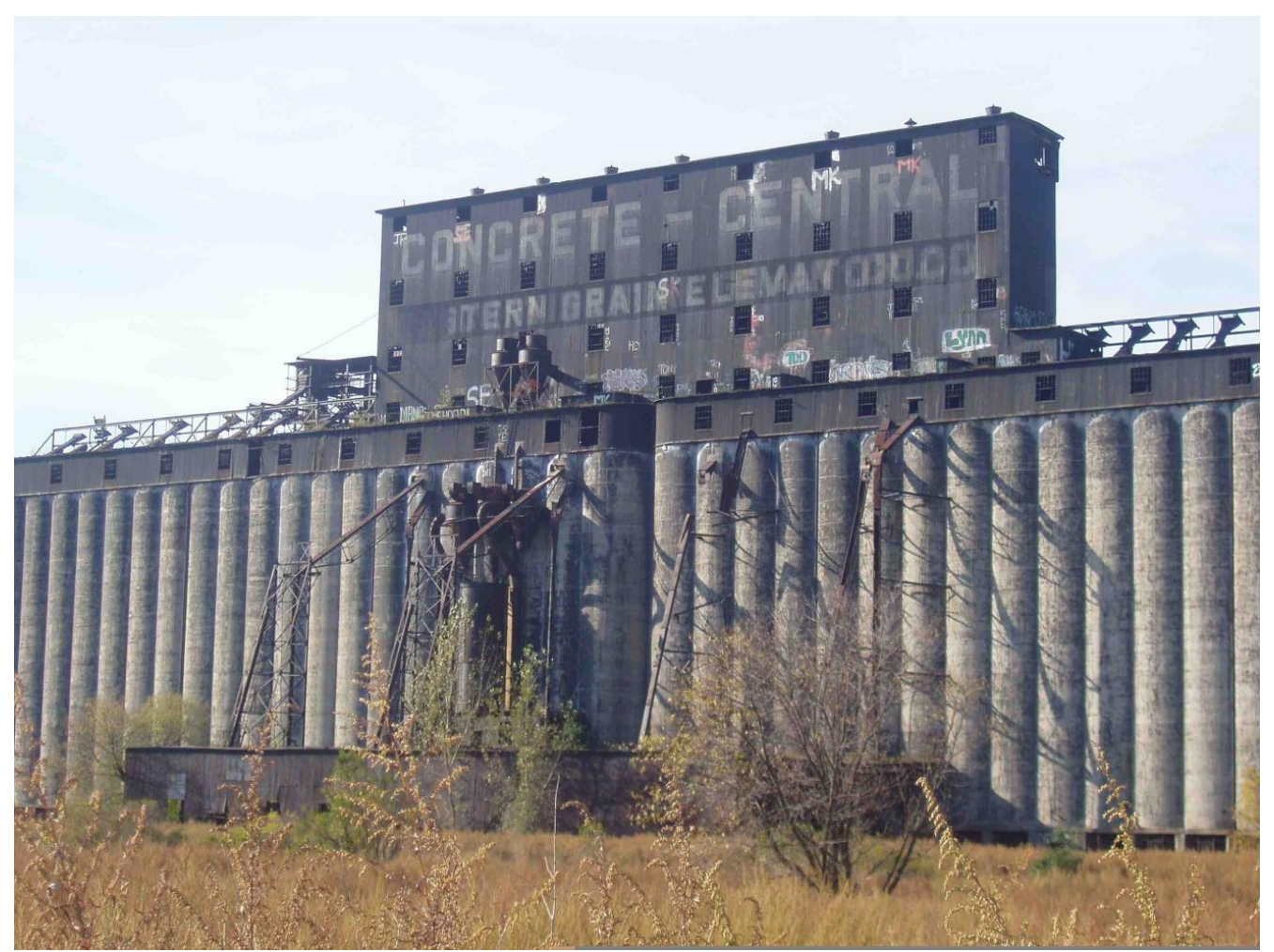

Figure 5. Concrete Central Silo, Buffalo, $N Y$

It is precisely with these models in mind that Gropius or Le Corbusier were to refer to building on a monumental scale. In his book, Entwicklung der moderner industriebaukunst, published in 1913, Gropius considered such buildings "pharaonic."4 In 1923, Le Corbusier recognized the added value of using reinforced concrete material in them. ${ }^{5}$ Contrary to what Le Corbusier suggested in Vers une Architecture, ${ }^{6}$ these proto-modern buildings were not designed by engineers but by multidisciplinary teams where the architect coordinated various kinds of knowledge involved in the process of professional know-how (Figure 5). Similar to Gropius and Le Corbusier and many other so-called masters of the Modern Movement, these professionals did not have an academic training but only

4. W. Gropius, "The Development of Modern Industrial Architecture," in Form and Function (London: The Open University; 1975), 53-55.

5. See Le Corbusier, Vers une Architecture (Paris: Flammarion, 1995).

6. Idem, 29. 
the practical experience gained in the studio or workshop as apprentices to architects/builders.

The advent of US protomodernity was the advent of the country's industrialization, where manufacturing as the basis of inventing American society was developed. It interpreted the functionalist spirit which Horatio Greenough wrote about in 1852 in a study called Form and Function. ${ }^{7}$ The truthfulness of the material and the building itself, responded directly to the functionalist architectural vision pictured by Horatio Greenough as being the future building expression particular to the USA. ${ }^{8}$

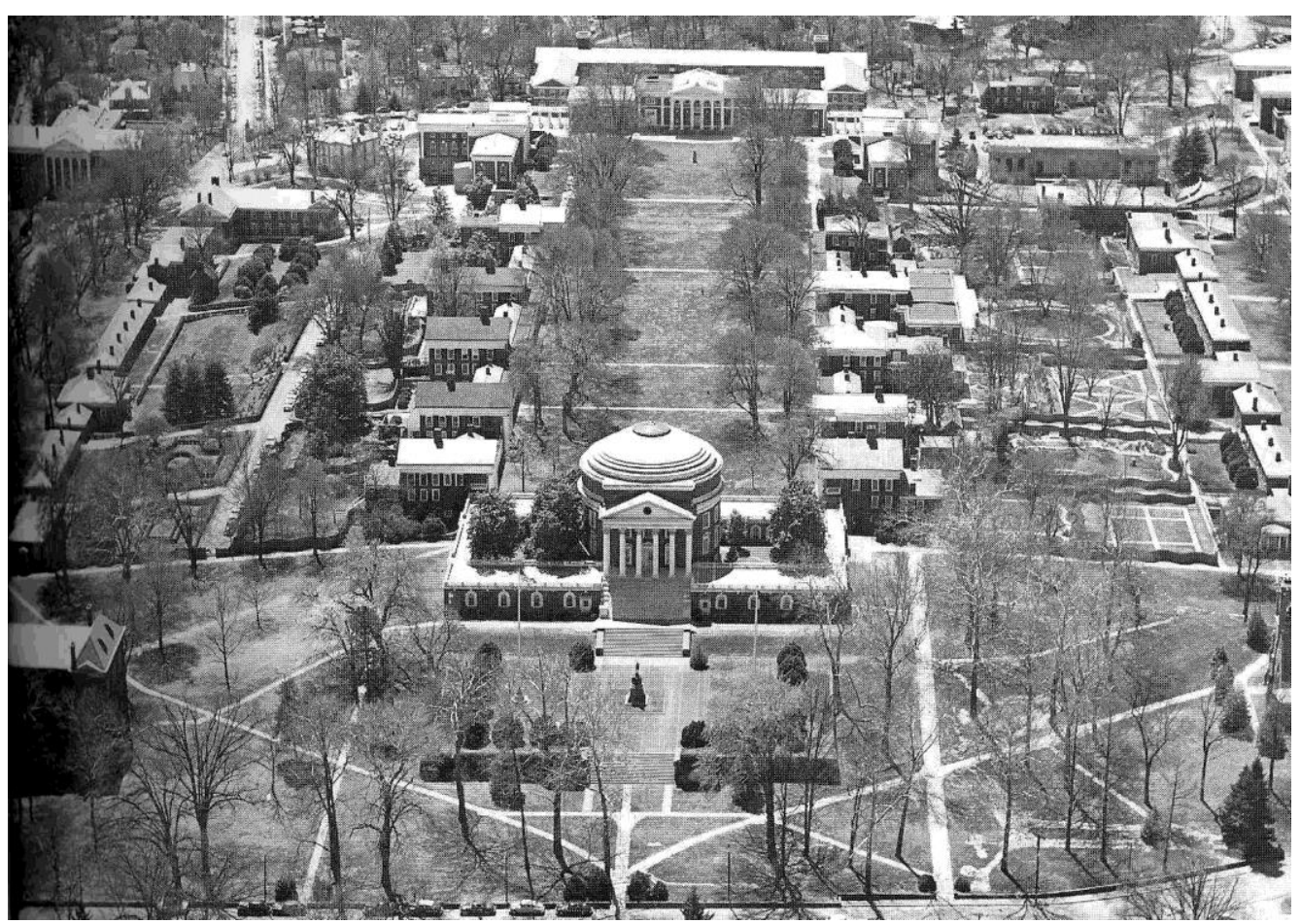

Figure 6. University of Virginia, Charllote Ville

Upon settling in virgin territory in the USA, a new organizational order was made possible. It was open to the territory itself, establishing its outmost boundary on the infinite, on the horizon, wiping the slate clean at the point of departure and moving (in topical and not utopian fashion) towards a new urban order (Figure 6).

7. See H. Greenough, Form and Function (Berkeley and Los Angeles: University of California Press, 1947).

8. Idem, 51-58. 


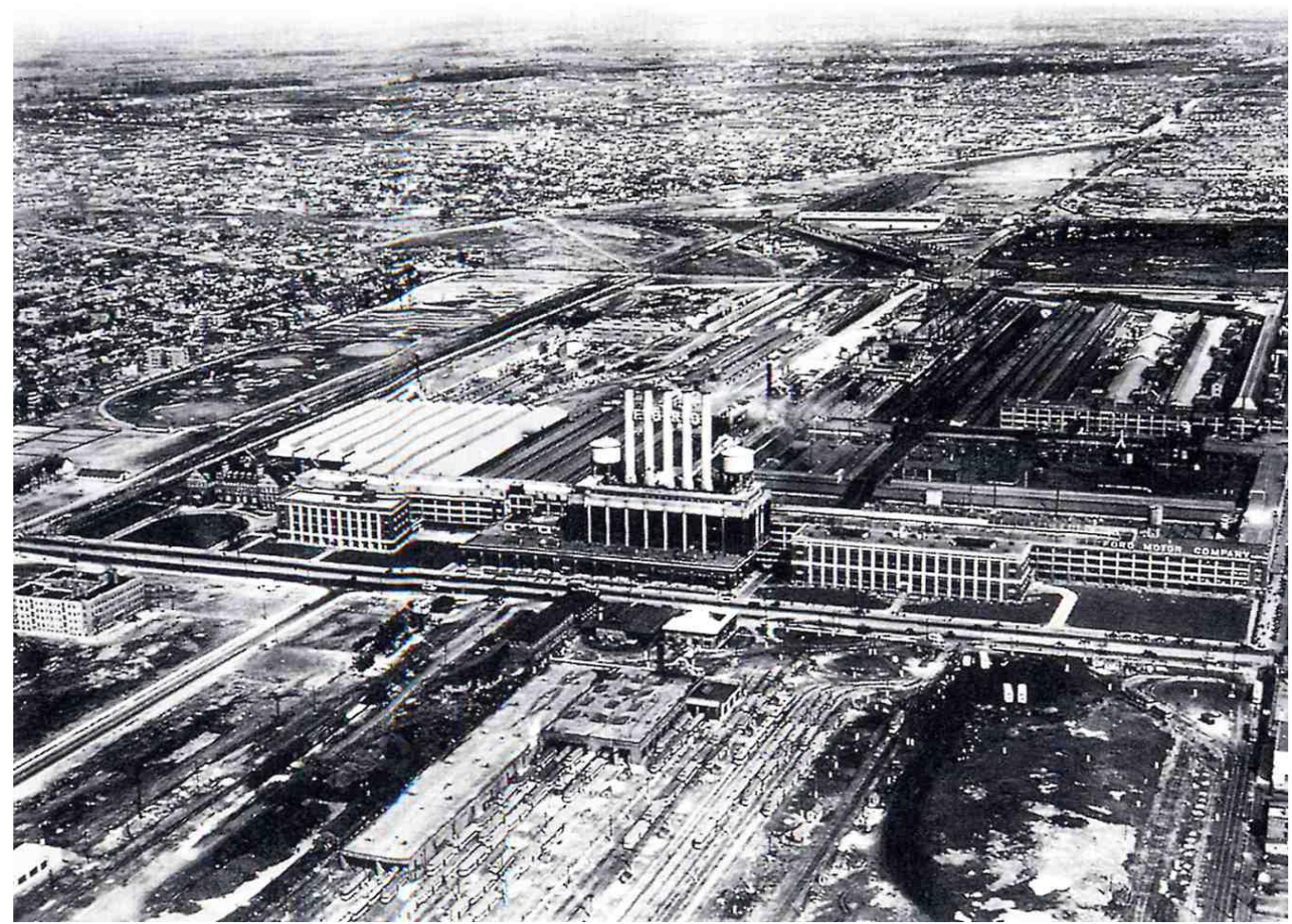

\section{Figure 7. Highland Park, Ford Industries, Detroit}

The ideal factory building in reinforced concrete took on this same peculiarity in the rule of limitless growth (Figure 7).

As such, it became the standard principle of design and building which gave it license to grow physically larger. The architect designing the factory building understood the factory in the light of its flexibility, growth, adaptability, functionality, economy and rationality.

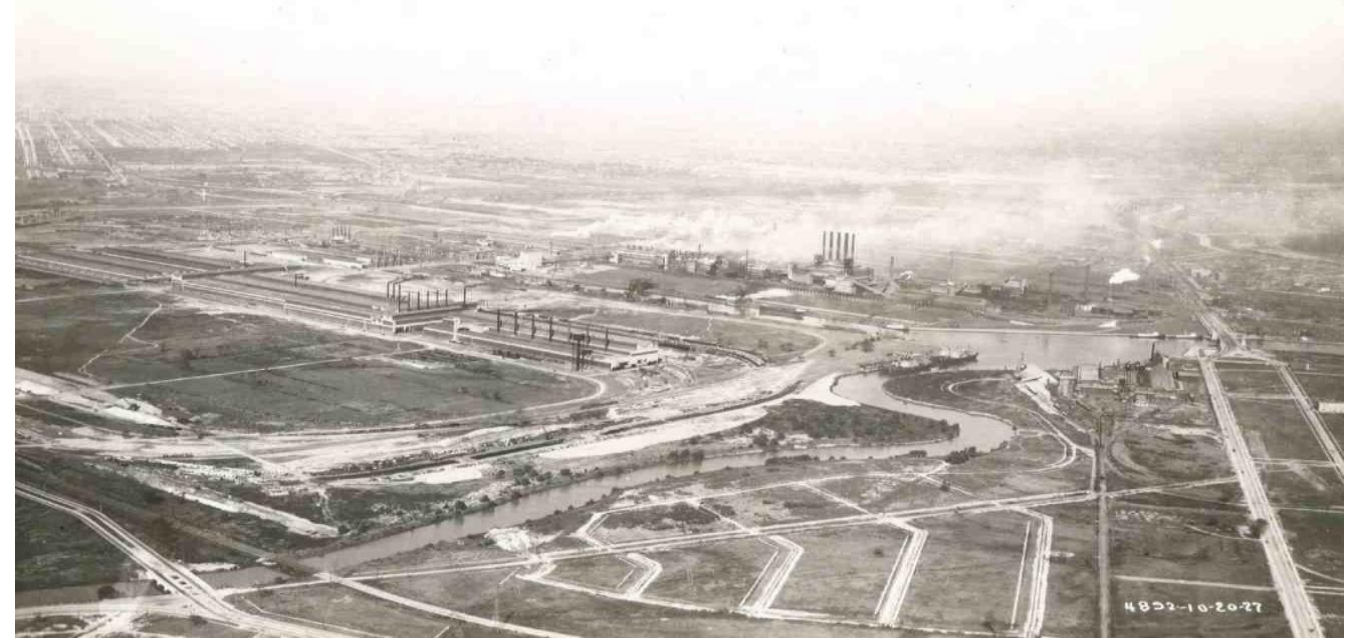

Figure 8. River Rouge Ford Compound, Detroit 
These notions were held dear in the modernist manifestos by the European vanguards. They were concepts formalizing the architectural models chosen by men such as Siegfried Giedion or Henry Russel-Hitchcock, although in the American's case, there was the pragmatic need to provide the new territory with the infrastructures heralding progress and the urgent build-up of a fully industrialized nation (Figure 8). Turning the USA into an industrialized country was a nation-wide aim seeking to organize society transversally and reach the American Dream on which the whole working-class structure was based.

The reinforced concrete factory became a protomodern architectural representation of this kind of society, not only in the way the building was organized and operated, but also in the explicit architectural choices underpinning its sections and/or divisions. The factory size and its multiple modules were celebrations of a certain formal anonymity which molded the entire country by means of a dimensional rule.

\section{The Packard}

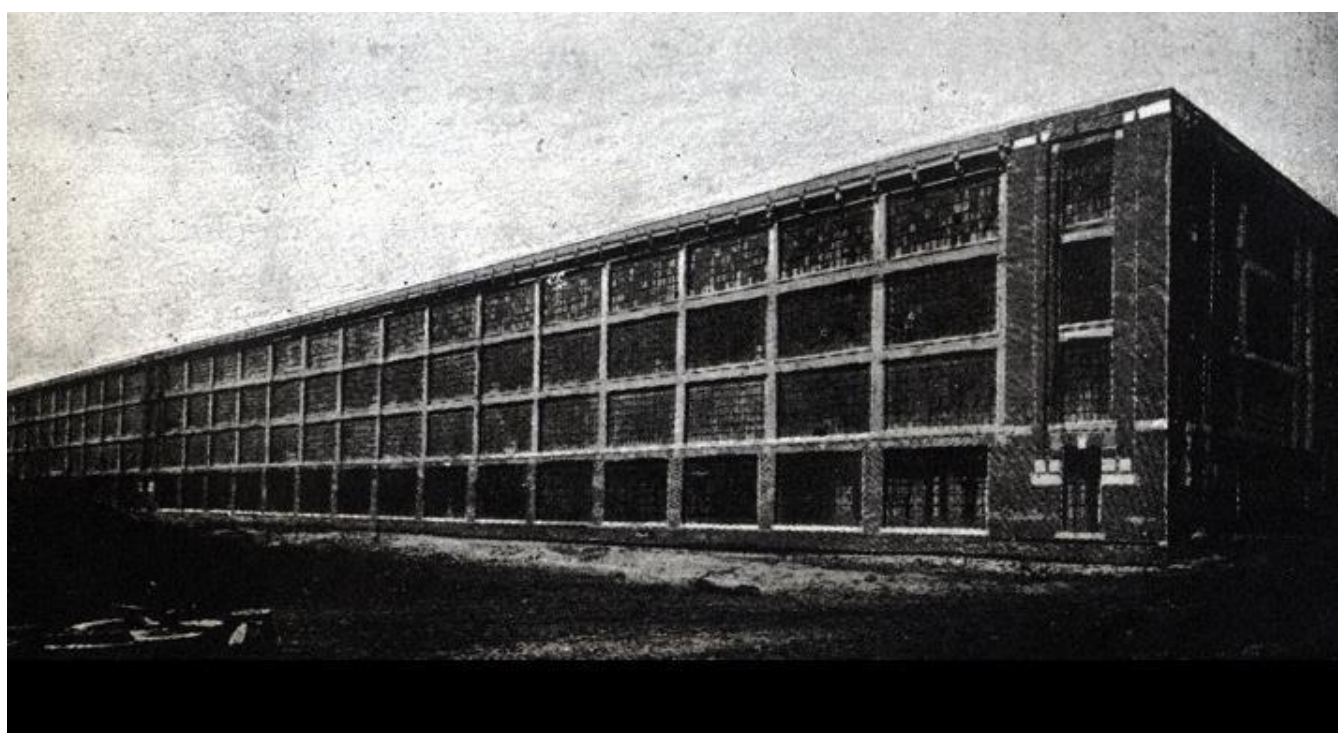

Figure 9. Highland Park Factory building, in Vers une Architecture, 1923, Le Corbusier

The architect made part and parcel of this expanding, producing enterprise that was as unrestricted in size as the prairie, although subject to the corporative structure of the industrial era. In this sense, architecture was one of the parts that fitted into gear. And if we are referring to the gear, it is because this idea portrays the notion of a special component of the machine working together with all the other parts to make it move. Moreover, any gear may be improved and redesigned so as to enhance the binary operational/performance aspects of the whole by the sum of its parts. The architect is only one of the parts that puts into practice the project organizing the physical, systemic environment of the factory. The ideal factory in reinforced concrete is in itself emblematic of the serial evolution in 
factory design. It is therefore a model which is open to change although closed to formal or intentional idiosyncrasies.

The Packard Motor Car Company factory in Detroit is, in itself, the distillation of Hitchcock and Johnson's theories despite the fact that it was built twenty years earlier. It bears none of the exceptions consistently introduced into buildings/ monuments that later made their way into the pages of modern architectural compendia. As a matter of fact, protomodernity represents the pure state of modernity by establishing a direct link between practice and the final result without leaving any trace of resistance in the global endeavor to regulate the working world.

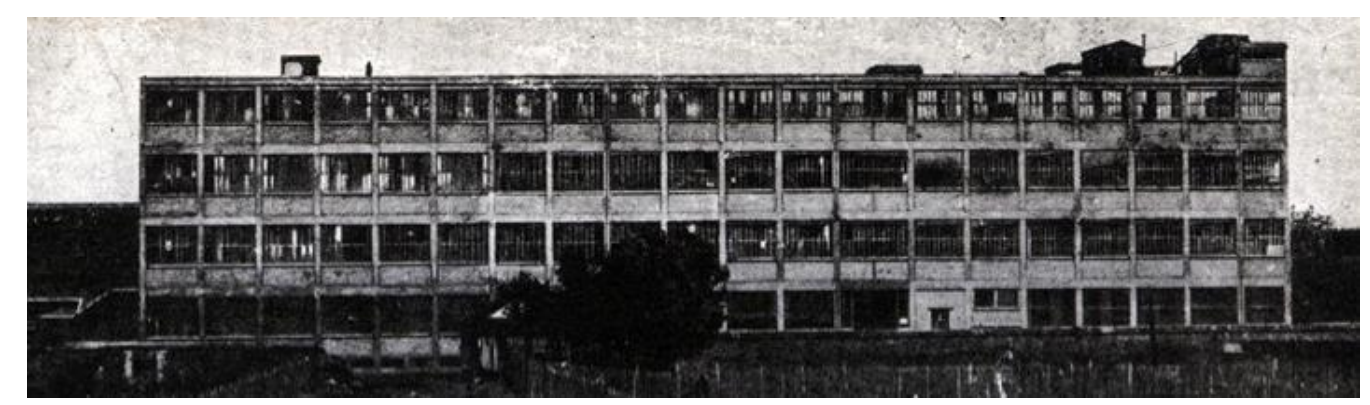

Figure 10. Packard Motor Cars Factory building, in Vers une Architecture, 1923, Le Corbusier

The new kind of program which the factory embodied gained enormous importance and significance in the first twenty years of the $20^{\text {th }}$ century in the USA. Due to its impressive size, it helped to define a new typology particularly in the heavy industrial complexes. It excited the admiration and "symbolic fascination" of some of the forerunners to the Modern Movement. For Behrens and Gropius, however, US factory models meant "aesthetic models" according to which architects had to undertake their work using the "traditional artistic disguise" that was characteristic of European architecture, in order to consciously "interpret the spirit of an age.",

Perhaps this is where the European masters, including Le Corbusier (Figures 9 and 10), made their mistake. They only took into account the metric scale of something that was much more complicated and that, professionally speaking, "put aside traditional aesthetic concerns" in order to focus on a new type of building by exclusively studying its practicability and its "operational and economic needs." 10 This position gave rise to new models giving new organizational solutions that always had to do with innovating urban occupations and situations.

Drawing up the plans of over 2,000 factories during his career, ${ }^{11}$ Albert Kahn worked at a time in which the machine exerted the greatest impact on daily life in all its history. He saw the advent of the motor car, the airplane, the lifting devices

9. G. Hildebrand, Designing for Industry, The Architecture of Albert Kahn (Cambridge, Massachusetts: The MIT Press, 1974), 2.

10. Idem.

11. Idem. 
in high-rise buildings and the urban elevator, and he noted the way in which they made part of modern $20^{\text {th }}$ century life. Kahn not only witnessed, through his professional and civil life, but actively took part in the modernization movement. He was highly pragmatic and despite the fact that he had little formal and theoretical education in the field of architecture and in the arts as a whole, Kahn became interested in working out a new type of building by making a combination of "program, structure and economy", relegating aesthetics and composition to the sphere of formalist or symbolic rules.

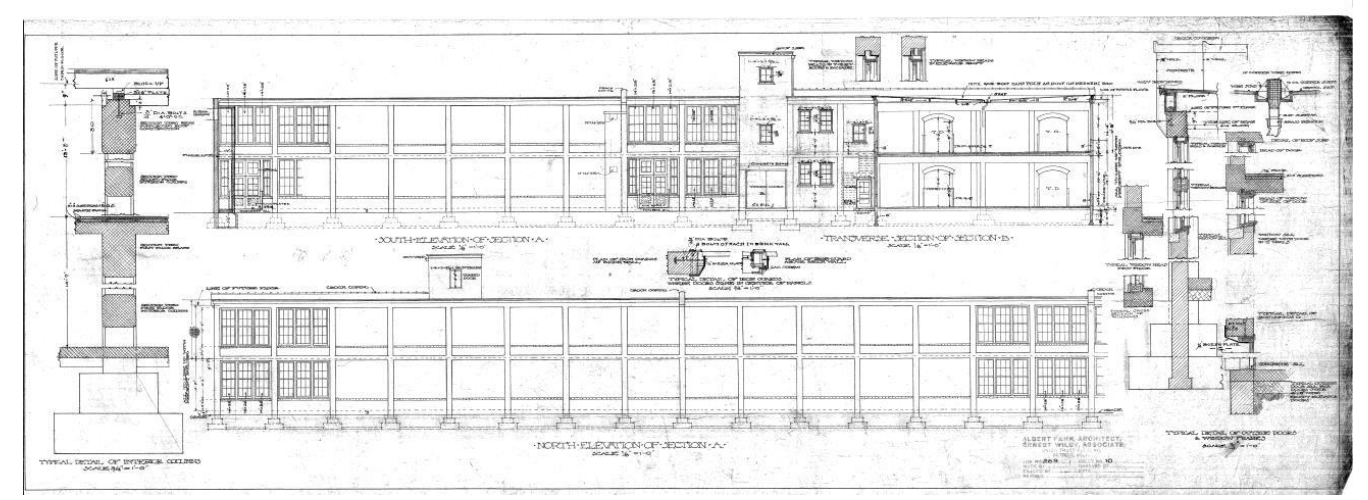

Figure 11. Technical Drawings for Packard Motor Car Factory, in Bentley Historical Library, University of Michigan, Anne Arbor

In this way, his "factual performance" was formalized into a building solution. ${ }^{12}$ Upon recognizing that his cultural pragmatism was devoid of erudite or traditional culture, Kahn sought the service of experts working in areas outside architecture and very often, outside the building industry. Factory buildings offered new types challenges due their operational complexities and new integrated systems demanding specialized engineering. These new building sciences became integrated into architecture thereby playing their part in forming much needed pluridisciplinary teams capable of coming up with new kinds of programs. ${ }^{13}$ They also responded directly to questions about safety and comfort at work, structural robustness and durability, malleable and flexible functional solutions as well as the inclusion of mechanical, hydraulic and electrical systems in buildings.

In 1902, Kahn was introduced to Henry B. Joy, the managing director of the Packard Motor Car Company's new Detroit-based factory. The Packard industrial complex underwent various stages of significant growth until about 1913. Although the factory continued to grow after this date, it did so based on models that had been put to the test in previous stages of growth. The first factory was built between 1903 and 1905 according to traditional masonry constructions in brick with wooden floors.

12. Idem, 3.

13. Idem, 2. 
In 1905, Albert Kahn designed building number 10 (Figure 11) together with his brother, Julius, who was working on his new reinforced concrete system, and constructed the first reinforced-concrete building in Greater Detroit. ${ }^{14}$

The need to reduce fire hazards and increase the span between the pillars, were reasons enough for the Kahn brothers to choose reinforced concrete for building the rest of the factory units in the complex. ${ }^{15}$

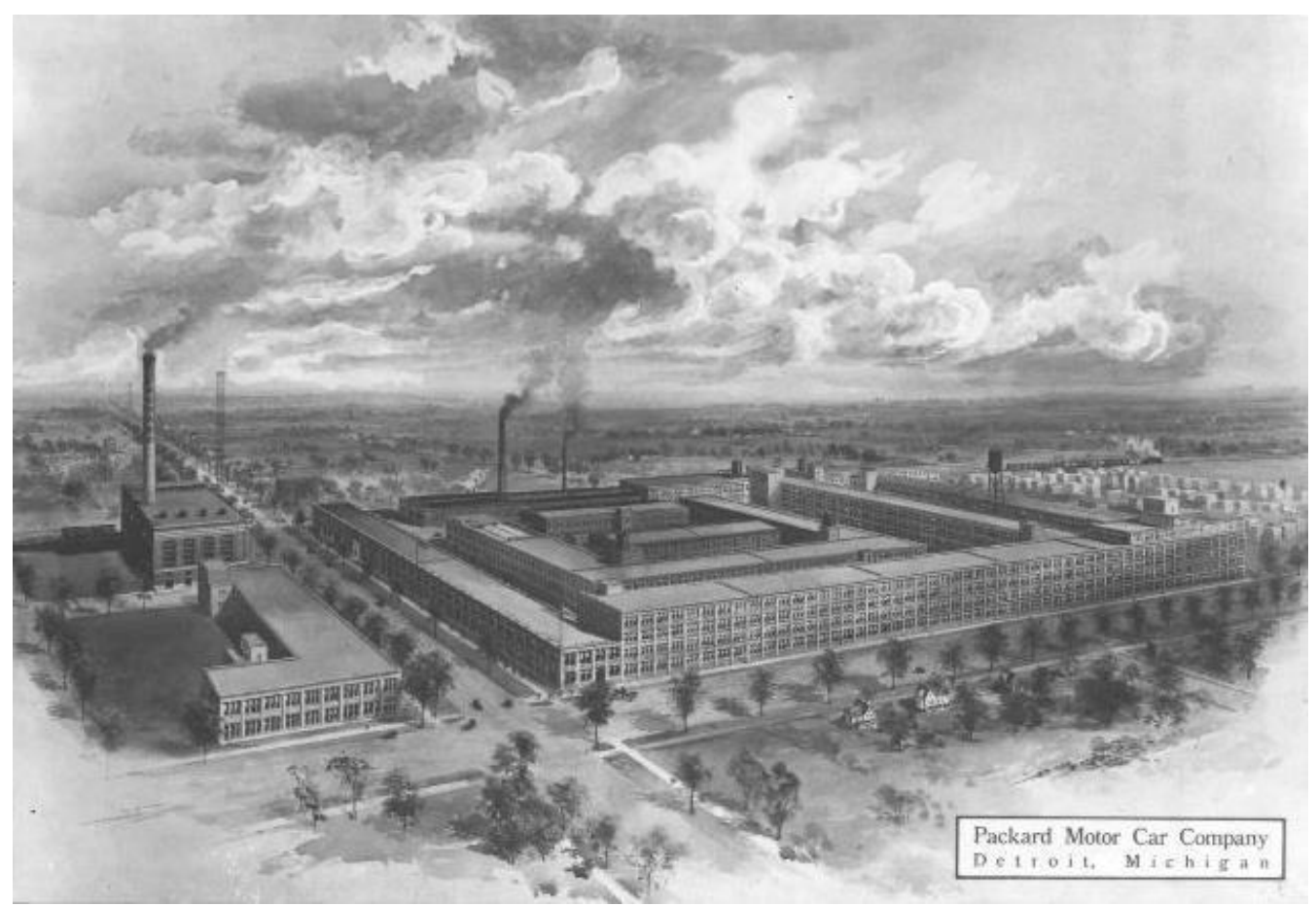

Figure 12. Packard Motors Car Company, circa 1910 in The American Architect and Buiding News, Vol XCIX June 14; New York: Hearst Magazines, Inc.

Reinforced concrete had another advantage in that it offered enormous possibilities in arranging and rearranging different kinds of layouts as well as extending work space, hitherto cluttered with metallic pillars about $3 \mathrm{~m}$ apart, by lengthening the span between the pillars to about $9 \mathrm{~m} .{ }^{16}$

The 1910 building campaign (Figure 12) in which new factory units and two extra floors were added to some of the existing office blocks, saw the definite replacement of the traditional brick or stone masonry with reinforced concrete. It was around this time that the power-house located south of the Grand Boulevard was also extended. There was further building work carried out on the factory until it finally closed down in 1956.

14. W. H. Ferry, The Legacy of Albert Kahn (Detroit: Wayne State University Press, 1987); Hildebrand, Grand, Designing for Industry, The Architecture of Albert Kahn, 1974, 28.

15. Ferry, The Legacy of Albert Kahn, 1987, 11.

16. F. Bucci, F. and A. Kahn, Architect of Ford (trans.) Carmen DiCinque (New York: Princeton Architectural Press, 2001), 31. 


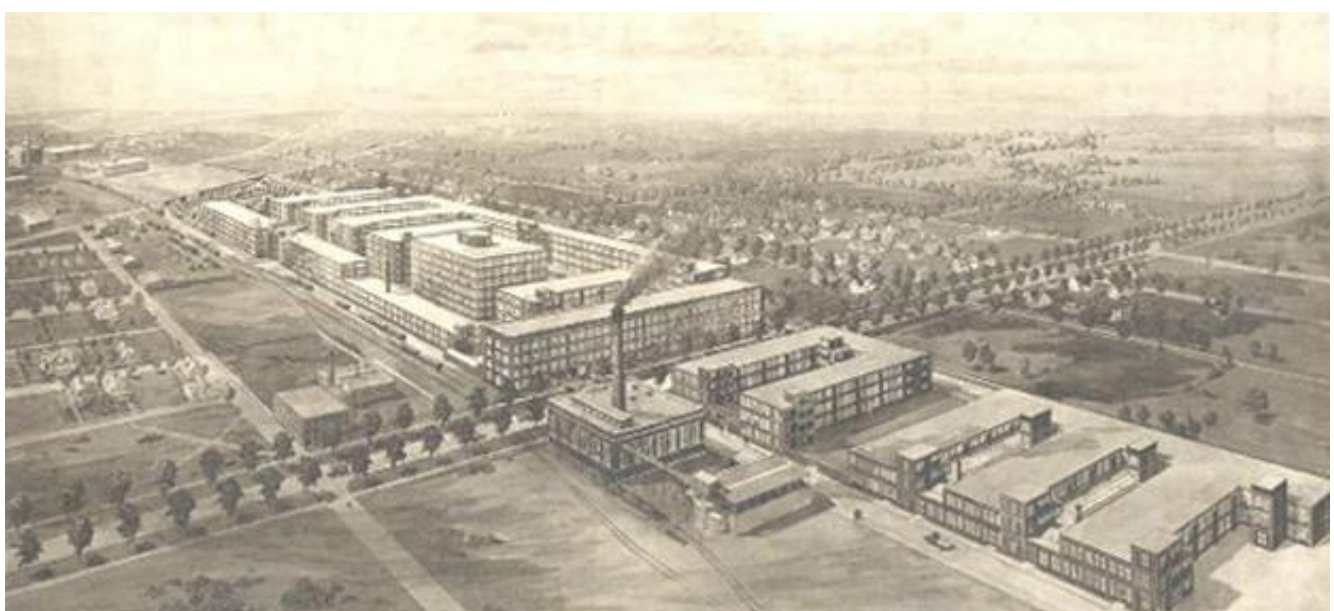

Figure 13. Packard Motor Car Company Factory, Rending Dated from 1913

Building experience at this time showed that the three basic demands of a modern factory were that it should be run economically, be free of combustible material and be well-lit, as well as have everything connected to as efficient a ventilation system as possible. ${ }^{17}$ Satisfying such demands would be as important to the factory managers and directors as it would be to its workers. Writing at the time, Charles Moore made a study of a factory suitable for the automobile industry, and more in particular of the Packard factory where he was the production manager. If a model could be drawn up for manufacturing buildings and in this case, for manufacturing automobiles - it would have to follow criteria based on the proximity and arrangement of the various parts and sections which, in turn, would need to obey the proximity between the sub-functions. To do this, Moore explained, it would be convenient to group several buildings and/or parts of the factory around a common warehouse. Therefore, around this central warehouse would be the various manufacturing sections of the factory while located behind them, would be the assembly plants where the manufactured object was put together.

This model would thus allow parts and materials to be moved between sections along the shortest possible route, thus facilitating communication among the different parts of the factory. The product would also be dispatched more efficiently because finished automobiles would leave the factory complex by way of the outer buildings. ${ }^{18}$

The Packard factory was organized into independent production modules (Figure 13). In each module, the heaviest materials were stored and brought into the building at ground-floor level. Car assembly worked as from the first floor and went up through the floors until reaching the top-floor where the automobiles were taken outside on goods-elevators. Each building housed the entire assembly process and after the whole factory complex had been given two extra floors,

17. C. J. Moore, "Some Essentials of the Modern Manufacturing Building: with Special Reference to the Packard Motor Car Company's Plant at Detroit," In The American Architect and Building News XCIX June 14 (New York: Hearst Magazines, Inc, 1911), 219.

18. Idem, 219-220. 
specialized automobile assembly was then carried out in them. We may speculate about whether the chassis was assembled to the motor on the ground floor, car interiors assembled on the floors above, the remaining parts of the car bodywork assembled on the third floor and finally, on the fourth floor, painting and car fixtures. After adding the two extra floors, it was likely that specialized activity was pursued and this is what Kahn would have been exploring mainly after he joined Henry Ford and built the Ford Motor Company factories.

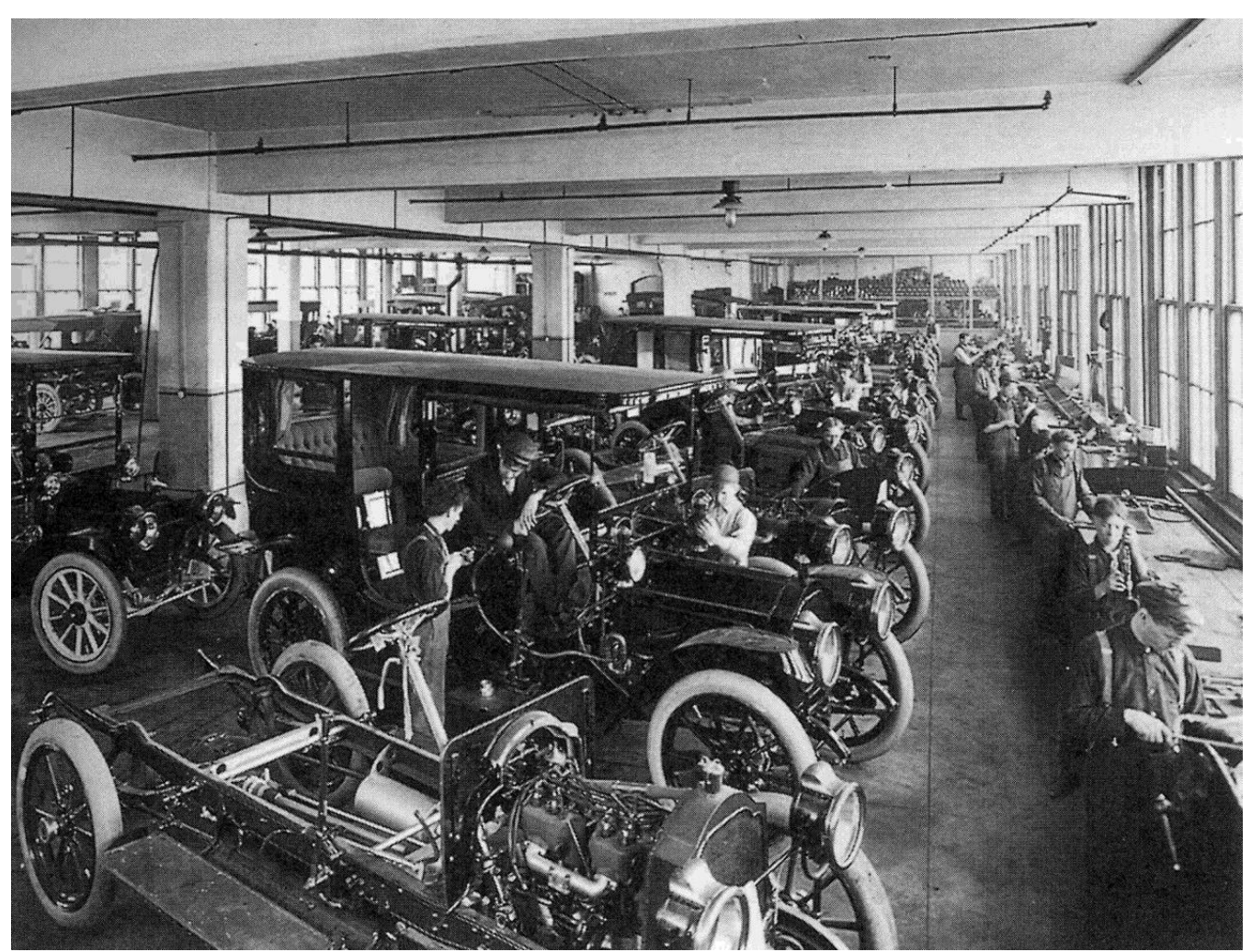

Figure 14. Interior View of the Car Shop, Image in the Albert Kahn Associates Detroit Office Archives

Nevertheless, at the Packard factory, the assembly buildings predominated because they were complete production units in themselves and each building produced as many finished automobiles as this full-cycle assembly method yielded (Figure 14). The system was geared to producing top quality or luxury automobiles in series, as Packard vehicles were, contrary to Ford's Model T aimed at all Americans and going into production in its new factory in Highland Park. At Packard's, the more assembly buildings there were, the more car production there was, because each building was supplied by the workshops backing up manufacture; each plant was totally independent in terms of production, thus assuring quality assembly and maximum production per unit. The spiraling growth of the original building center located to the north of the Grand Boulevard, was similarly based on the incremental growth witnessed in the southern section where there were many more new buildings being added on the original structures owing to the type of growth and expansion in progress. Buildings to the south revealed 
the principle of incremental growth much more clearly. Each of the bits added on was completely independent not only from the operational point of view, as the buildings in the northern part were, but also from the formal and organizational point of view of the buildings as a whole.

The functional connection through the top of the buildings in the north was temporarily abandoned by simply relocating the production plant in a module that had been added on. Probably encouraged by Frederick Taylor's theories, this new module resembled a model of growth directly connecting architecture and growth phenomena, based as it was on adding more buildings to full-cycle production plants. This kind of development model was to be drastically changed when Kahn designed the Highland Park building in which Henry Ford's assembly lines revolutionized factory modes of organization. In all appearances it seemed a return to the model of growth linking the tops of buildings, although in this case running factors were clearly connected to the growth of assembly-line manufacturing.

Mention should also be made about the railroad branching off from Michigan Central as it brought with it nation-wide connections. The railroad ran alongside the factory complex and was used to send the automobiles to other areas in the USA as well as ensure the connection with the Forge Shop and the truckmanufacturing plant situated to the north of the automobile plant. The organizational model of the factory at this stage did not wholly depend upon horizontal connection, as it did in later factories, so the railroad only had relative importance here.

All these building or parts of buildings were made of reinforced concrete. There were walls and fire- proof doors between each production plant. The doors were periodically inspected to test their working order and resistance in the event of fire. ${ }^{19}$ When designing and planning the factory complex, every attention was paid to the position of these protective devices, curettes, equipment and machinery together with the ventilation and extraction systems that were essential for the smooth running of the plants. An entire reinforced-concrete factory building demanded that such systems and equipment had to be carefully studied right from the very beginning of the project owing to the building's contained shape and difficulties in correcting structural errors later on. ${ }^{20}$

Nevertheless, the fact that a structure in reinforced concrete (Figure 15) tended to offer flexibility in usage consequently affecting its formal organization, was such that in this complex - despite the fact that certain sections had to bear different weights as for instance, the warehouse supplying the manufacturing and assembly plants where even if the weight was lighter, the vibrations in these plants caused considerable stress on the structure - this kind of building was chosen precisely because it could be made to adapt to all the specific requirements of each section or plant. ${ }^{21}$

19. Idem, 220.

20. Idem.

21. Idem. 


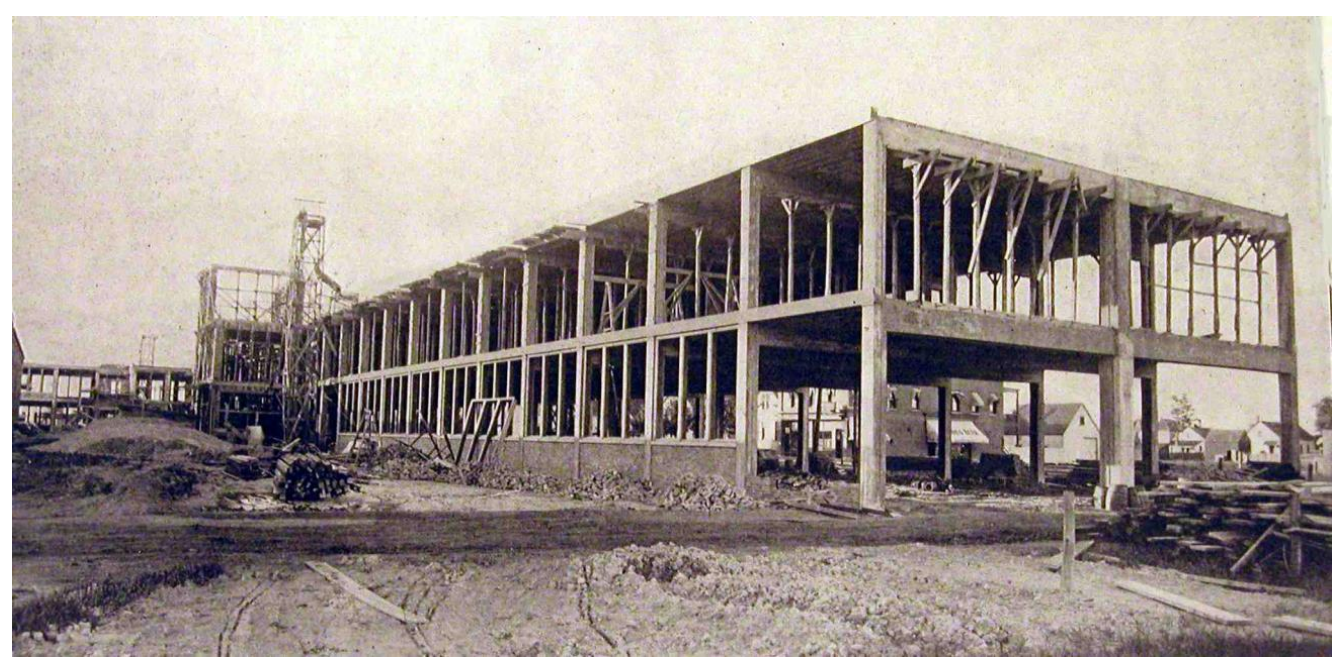

Figure 15. Packard Motor Car Company Factory Building no 11, The Atlas Portland Cement Company, Reinforced Concrete in Factory Construction; New York, 1907, 144

This being the case, the larger spaces were reserved for areas that needed more light and less weight; more vertical piers were put in stock or warehouse buildings; there were different kinds of floor paving which could be in cement, or in wood if it was in the daily work place; more attention was paid to noise levels, etc. All these measures were applied in Packard's factory although, in some cases they were considered to be finishing touches and incidental wooden fixtures (e.g. some of the wooden floors), so that over time, they tended to be phased out due to safety measures and protection against fire hazards.

Packard's was completely outfitted with electricity where the wiring was apparent, running through beams where necessary and going along the floor boards so as not to interfere with daily factory routines. ${ }^{22}$ There was also a ventilation and heating system where tubes and conduits ran along the outer walls of the building, reaching all floors. The equipment needing extraction or forced air were located on the lowest floor. ${ }^{23}$ Although it was usual to have a central block reserved for lockers and washrooms accommodating all the workers in the factory, Packard chose to build small sanitary blocks in each work place to ensure better hygiene and allow the worker to change into his street clothes before leaving the job. $^{24}$

Under the factory complex, were the engineering vaults where the steam and water pipes and wiring for all the buildings composing the different sections of the factory ran to the powerhouse. ${ }^{25}$

This arrangement not only ensured the smooth running and link up between all parts of the factory, which meant economizing on the daily running costs in the car manufacturing process, but it also meant a significant improvement in the

22. Idem, 221.

23. Idem.

24. Idem.

25. Idem. 
environmental quality of the work place, and as such, played an important role in the workers' mental health.

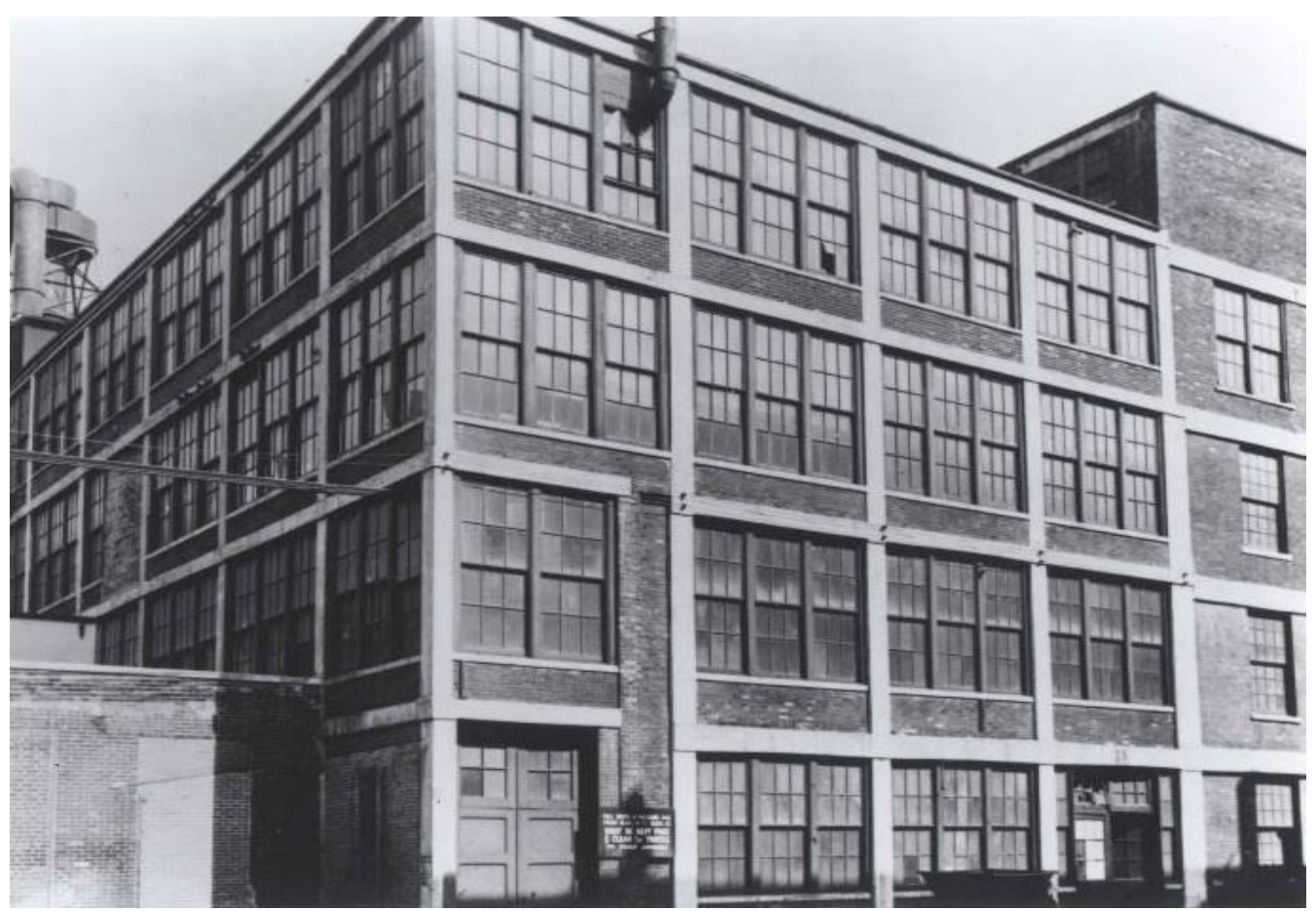

Figure 16. Packard Motor Car Company Building no 10, Image in the Albert Kahn Associates Detroit Office Archives

Building number 10 (Figure 16) has normally been referred to as a cornerstone in the history of reinforced concrete in the USA as well as in the rest of the world, due to the fact that it used reinforced concrete as a building method and knew the value of concrete. In fact, the novelty of Building No. 10 may be summarized in its material nature and construction that were open to technical and stylistic innovations introduced in this particular field of architectural history.

Nonetheless, Kahn's contribution in these projects, together with Building numbers 1 to 9 in traditional masonry and wood, helped to contextualize the value of architecture in a new way when it came to dealing with industrial production. The several kinds of factories in the industrial site represented ways of organizing activity undergoing constant change as it kept abreast of the progress industrial technology was making which, in turn, affected organizational modes. The factories had multiple flexibility: they were added on to vertically and horizontally or parts of them were demolished and rehabilitated. As a whole, the value of the factory was limited to the duration of production so that when production stopped or changed, the building could be demolished, replaced or altered. These structures were not meant to last forever, unlike the architecture of the past. One of the key factors for the successful growth and possible redesigning of the Packard factory building complex, lay in its structural modules that allowed for flexibility in the organizational composition of the modules. 
The program was like playing a game based on spatial needs according to the roles the different activities had in the manufacturing process in abstract terms. In other words, if they had no occupation or were not integrated into a precise functional scheme, the modules failed to exist in themselves. When the scheme changed, the layout also changed in the way it accommodated the new mode of functioning.

Bucci referred to this building as the first to conjugate its entrails with its outer skin. ${ }^{26}$ Harmonizing this conjugation was an inherent concern in all the utilitarian projects Kahn was to subsequently draw up, mainly for factory buildings. In spite of his departure point with Packard No. 10, he improved and changed quite markedly throughout his architectural career that lasted more than 40 years. The first daylight factory appeared in all its "shamelessly naked purity." 27

But it is this "null value condition, the zero term of architecture" ${ }^{28}$ that places this building twenty years ahead of its time as far as the progressive values of the architecture of the Modern Movement go - values that were patent in the MoMA Exhibition of 1932.

\section{Conclusions}

The importance of Packard factory numbers 10, 11 and 12 resides not only in the truthfulness of the material and the building system as a new functional language in architecture, but in its ability to adapt and grow due to the regularity of its bays spanning the spaces between pillars and structural systems. The pragmatic attitude used by Kahn's office when designing Packard's factories allowed architecture to be approached from a scientific, objective angle. Making architecture more objective became an important, systematic way of working when Kahn's office drew up projects. Slight changes were introduced with the idea of enhancing the future factory's performance and its layout was constantly being reevaluated. It was essential to turn this incremental, pragmatic and empirical knowledge into practical know-how and by doing so, Kahn gained recognition as an architect specializing in building factories or industrial structures. It gave him the sort of experience needed to trace out his eventual future success amid the industrialists who were the final promoters of industrial architecture.

Finally, we need to mention the incorporation of infra-structures into reinforced concrete structures. Security systems, heating and electrical installations were incorporated into the building by means of drawing up particularities in the project. What may seem banal today, meant a true revolution in architectural practices at that time. The architect was no longer the enlightened author in charge of all the building steps; he now had to coordinate his work with other specialists and other kinds of knowledge that were located outside the sphere of architecture.

26. Bucci and Kahn, Architect of Ford, 2001, 31.

27. R. A. Banham, Concrete Atlantis: U.S. Industrial Building and European Modern Architecture 1900-1925 (London: The MIT Press, 1986), 84.

28. Idem, 86. 
If, in a certain way, a clear separation of the fields of knowledge and building skills was implied with the structure, then with all the new technological phenomena that had to be integrated into the building for the sake of its safety, comfort, workability and performance, the building had to comply with Taylor's theories finally published in 1911, and stating that maximum prosperity placed at the worker's disposal generated the worker's maximum efficiency. ${ }^{29}$ Prosperity was understood to mean prosperous working conditions, or rather healthy working conditions (that were well-lit, clean, ventilated, heated and safe) with decent pay (Figure 17).

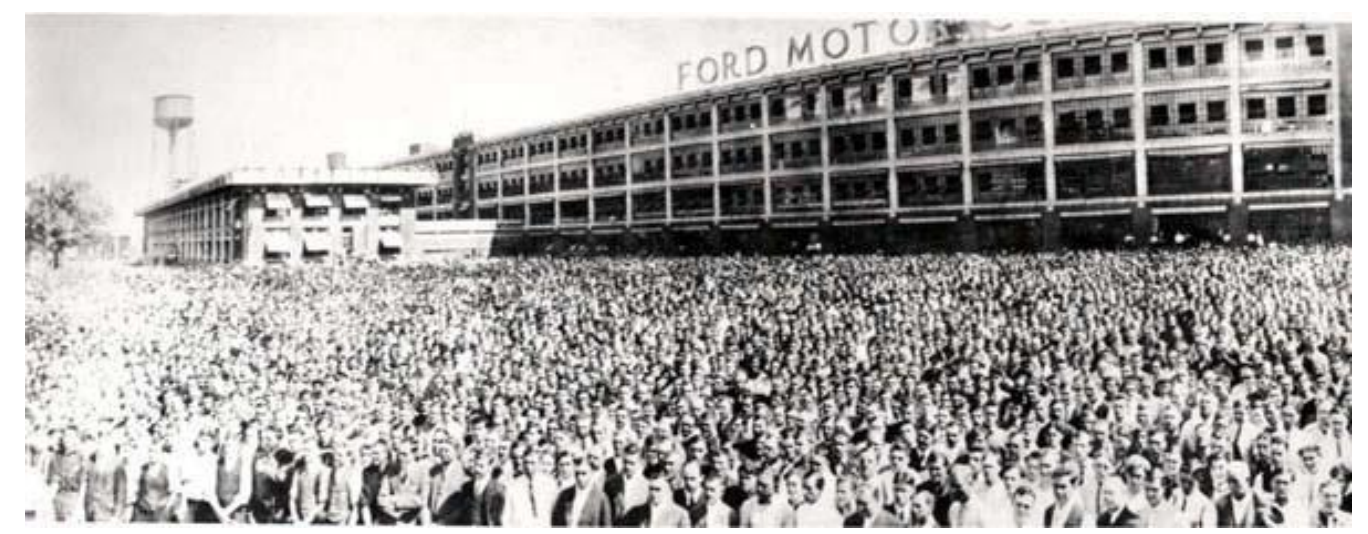

Figure 17. Highland Park Factory Building, Launching Day for the 5US\$ Campaign, Detroit

The specific importance of the Packard Motor Car Company lies precisely in the historical lesson it teaches about current practice exerted on modern architecture. The Protomodern here is shown to be a model of the Modern, while the Modern following it consisted of possible variations on the qualitative regularity of a building, so as to make it unusual. But the series, the regular building, the anonymous work and its territorial setting should be understood in the same way that the Mannerists knew more about the Renaissance treaties than their predecessors, thus making them better equipped to criticize them and reinvent their characteristics in architecture.

29. F. W. Taylor, The Principles of Scientific Management (Mineola, New York: Dover Publications, Inc, 1911), 1. 


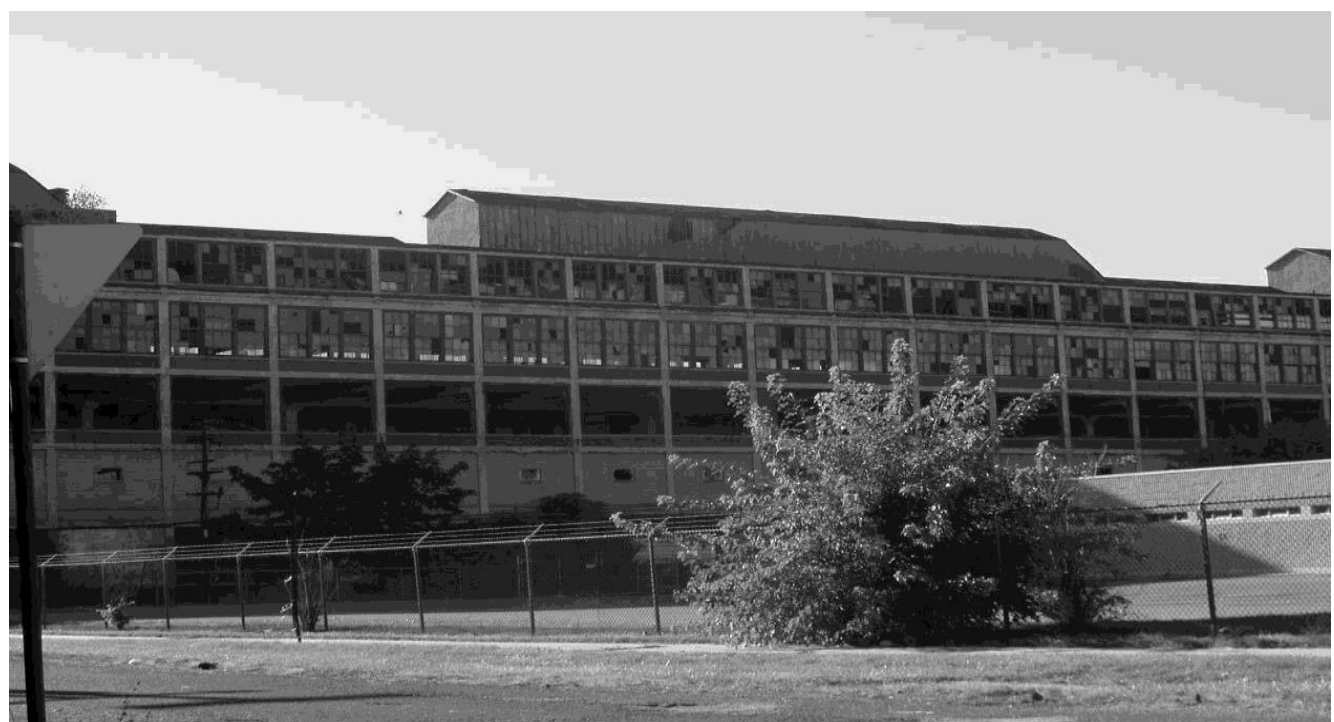

Figure 18. Packard Motor Car Company Factory Present State

The Packard factory finds itself suspended in time, a ruin standing over a large suburban tract (Figure 18), although it has been preserved and may yet be integrated into the somewhat rarefied urban tissue on the outskirts of Detroit. There are few industrial complexes dating from the first ten years of the $20^{\text {th }}$ century that show the structural and functional plenitude as is shown by the Packard factory. In the same way, there are even fewer buildings which, in themselves, express the functionalist notion that changed the way of building and understanding architecture with the Modern Movement.
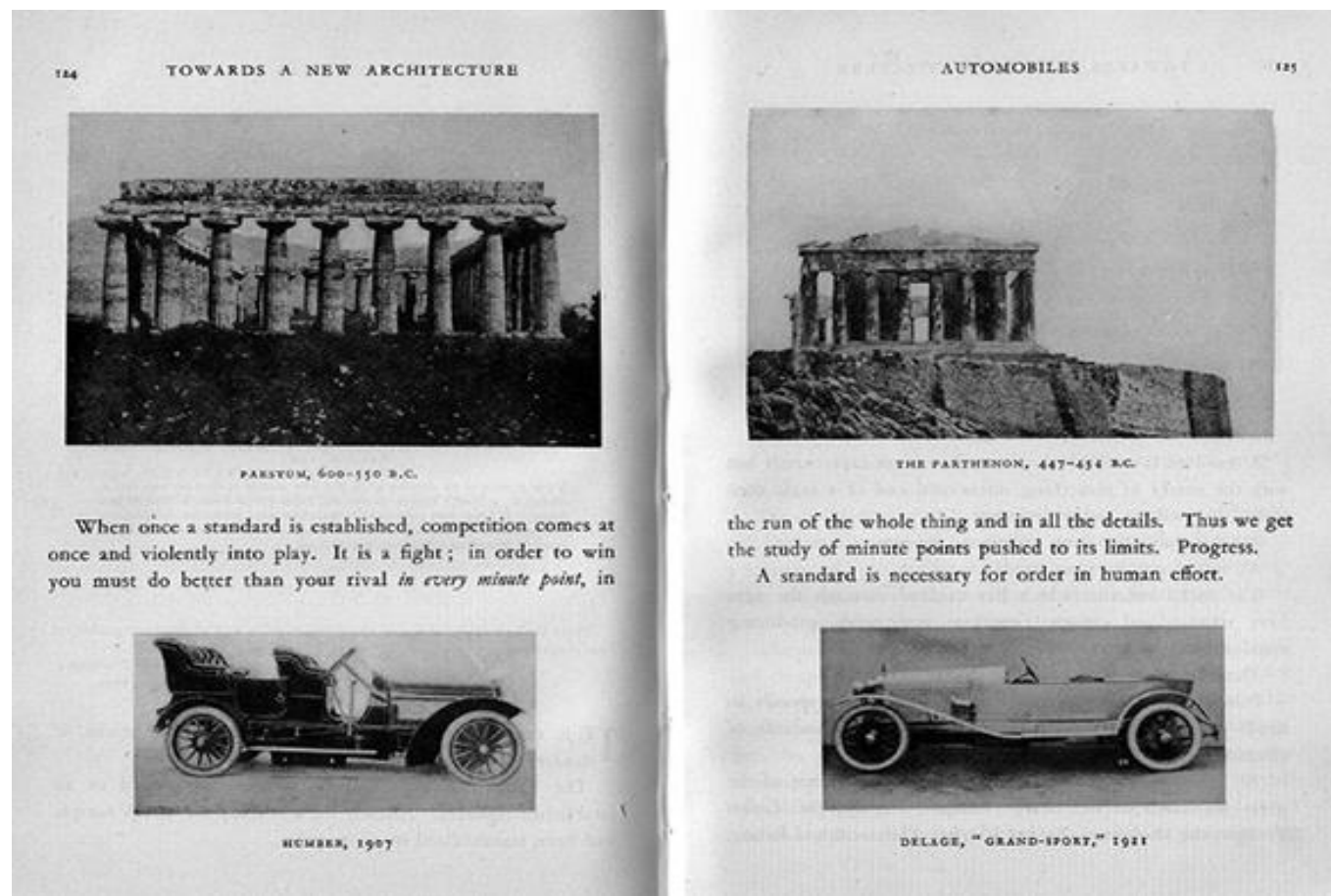

Figure 19. Parthenon and the Modern Automobile, in Vers une Architecture, Le Corbusier, 1923 
The Packard stands for the History of Modern XX Century Architecture as the Partenon stands for all Classic Architectonic Culture (Figure 19).

\section{Bibliography}

Banham, R. A Concrete Atlantis: U.S. Industrial Building and European Modern Architecture 1900-1925. London: The MIT Press, 1986.

Bucci, F. and A. Kahn. Architect of Ford. Translated by Carmen DiCinque. New York: Princeton Architectural Press, 2001.

Ferry, W. H. The Legacy of Albert Kahn. Detroit: Wayne State University Press, 1987.

Greenough, H. Form and Function. Berkeley and Los Angeles: University of California Press, 1947.

Gropius, W. "The Development of Modern Industrial Architecture." In Form and Function. London: The Open University; 1975, 53-55.

Hildebrand, G. Designing for Industry, The Architecture of Albert Kahn. Cambridge, Massachusetts: The MIT Press, 1974.

Hitchcock, H. R. and P. Johnson. The International Style. New York and London: W. W., 1995.

Le Corbusier. Vers une Architecture. [Toward and Architecture.] Paris: Flammarion, 1995.

Moore, C. J. "Some Essentials of the Modern Manufacturing Building: with Special Reference to the Packard Motor Car Company's Plant at Detroit." In The American Architect and Building News XCIX June 14. New York: Hearst Magazines, Inc, 1911.

Taylor, F. W. The Principles of Scientific Management. Mineola, New York: Dover Publications, Inc, 1911. 